\title{
PANDANGAN GURU DALAM PENGEMBANGAN KURIKULUM PENDIDIKAN KHUSUS
}

\section{TEACHERS' VIEWS IN SPECIAL EDUCATION CURRICULUM DEVELOPMENT}

\author{
Sutjipto \\ Pusat Kurikulum dan Perbukuan, Badan Litbang, Kemendikbud \\ Jl. Gunung Sahari Raya, Nomor 4A, Jakarta Pusat. \\ E-mail: sutjipto.55@gmail.com
}

Naskah diterima tanggal: 25-1-2018, disetujui tanggal: 8-6-2018

\begin{abstract}
The purpose of this research is to comprehensively examine the views of special school teachers in the development of special educational curricula on the design and principles. The research involved fourty three teachers froms eight different special schools. Data was collected through forum group discussion dan analyzed by descriptive qualitative method. The results show, first, from the teacher's point of view, that in designing a special educational curriculum for learners with special needs it should contain practical knowledge, moral character qualities and performance, essential skills, competence, art, and literacy praxis. Secondly, flexibility, functionality, independence, literacy, and vocational are the principles of developing a special education curriculum for learners with special needs.
\end{abstract}

Keywords: teachers' views, curriculum development, curriculum principles, special education

\begin{abstract}
Abstrak: Penelitian ini bertujuan untuk mengkaji secara komprehensif pandangan guru sekolah luar biasa dalam pengembangan kurikulum pendidikan khusus pada dimensi perancangan dan asasnya. Penelitian melibatkan empat puluh tiga guru sekolah luar biasa dari delapan sekolah. Data dikumpulkan dengan menggunakan teknik diskusi kelompok terpumpun dan teknik analisis data menggunakan deskriptif kualitatif. Hasil penelitian menunjukkan bahwa dari sudut pandang guru dalam perancangan kurikulum pendidikan khusus untuk peserta didik berkebutuhan khusus harus mengandung muatan-muatan pengetahuan praktis, kualitas karakter moral dan kinerja, keterampilan penting, kompetensi, seni, dan praksis literasi. Selain itu, keluwesan, fungsional, kemandirian, literasi, dan kejuruan merupakan asas-asas pengembangan kurikulum pendidikan khusus bagi peserta didik berkebutuhan khusus.
\end{abstract}

Kata kunci: pandangan guru, pengembangan kurikulum, azas kurikulum, pendidikan khusus

\section{PENDAHULUAN}

Dinamika penyusunan kurikulum pendidikan khusus yang selama ini disebut sekolah luar biasa (SLB) antara lain menyangkut pembahasan ide kurikulum, perancangan kurikulum, kegiatan pelatihan guru dan tenaga kependidikan, pendampingan implementasi, dan penulisan buku pendukung pelajaran. Dalam konteks tersebut, dapat dikatakan khas karena mampu memberi warna baru dan melibatkan guru hingga ke pelosok negeri. Hal ini diperkuat kajian Spence dan McDonald (2015) yang mengatakan bahwa kita belajar untuk melihat dunia melalui mata baru, bagaimana kita mengubah interpretasi kita tentang pengalaman dan bagaimana kita mengubah pandangan kita tentang realitas. 
Apabila sudut pandang guru ditempatkan secara proporsional dalam penyusunan konsep perancangan dan konten kurikulum maka akan lebih mudah merangsang penyusunan lateral pengetahuan maupun kompetensi yang dibutuhkan peserta didik berkebutuhan khusus.

Terdapat beberapa rasionalitas mengapa pemangku kepentingan perancang kebijakan mengetengahkan semangat penyusunan kurikulum yang melibatkan guru. Pertama, adanya keinginan untuk menawarkan tantangan dan peluang bagi para guru untuk terlibat secara aktif dalam menyusun sebuah kurikulum yang khas, seperti ide dan desain, metodologi, pembelajaran, pengelolaan kelas, dan sistem penilaian. Pola kerja penyusunan seperti ini membutuhkan kerja sama berbagai pihak yang berkepentingan. Mengutip pernyataan Rock, et al. (2016), butuh keberanian dengan ajakan bertindak agar menghayati terwujudnya pendidikan dan pembudayaan yang sarat makna.

Secara teoretis, pengembangan kurikulum pendidikan khusus sejak dulu tidak berubah. Hakikat kurikulum secara prinsip mempunyai kesamaan, yaitu sebagai rancangan pembelajaran yang berupa seperangkat rencana untuk membangun dan memberdayakan potensi peserta didik. Perbedaan kurikulum yang dikembangkan terletak pada muatannya. Perbedaan muatan disebabkan oleh filosofi dan kepercayaan (beliefs), konteks, dan kondisi yang dimiliki dan dihadapi oleh kekhasan jenis pendidikan. Oleh karena itu, aktivitas kepakaran tim pengembang tidak pernah akan selalu dibutuhkan walaupun untuk konteks yang sama. Secara naluri, selalu ada kecenderungan pada diri pengembang untuk menghasilkan rancangan yang human dan berdasarkan kebermanfaatan yang tinggi.

Kedua, pelibatan guru dalam mengembangkan sebuah kurikulum untuk pendidikan khusus merupakan sebuah pengalaman dan tantangan baru. Guru meyakini bahwa kurikulum merupakan instrumen penting dan strategis untuk mendorong perubahan sosial masyarakat di sekitarnya yang senantiasa dikaitkan dengan harapan dan tantangan masa depan. Tantangan masa depan begitu kompleks, seperti globalisasi dan berbagai isu yang berkaitan dengan masalah lingkungan hidup, kemajuan teknologi informasi dan komunikasi, turbulensi ekonomi, kebangkitan industri kreatif, perubahan budaya, dan perkembangan ranah pendidikan di semua tingkatan. Itu semua membutuhkan tanggapan yang segera terwujud dalam kurikulum.

Ketiga, mekanisme kerangka kerja pengembangan kurikulum selama ini kurang melibatkan guru dan dianggap kurang menyentuh pengalaman baik mereka. Hal ini dapat dimaknai kurang mendekatkan faktafakta sosial yang ada di sekitar peserta didik berkebutuhan khusus. Pola kerja tersebut kurang terbuka mewadahi sudut pandang guru terkait gagasan-gagasan terhadap pengembangan kurikulum. Kurangnya keterbukaan pelibatan guru ini diperkuat temuan Li dan Laidlaw (2006) dalam penelitiannya tentang esensi kerja sama, penelitian tindakan kelas, dan penyusunan kurikulum di Cina pedesaan yang mengatakan pentingnya menjaga pikiran terbuka dalam meningkatkan wawasan pengembangan suatu kurikulum. Apabila strategi kerja pengembangan kurikulum yang kurang melibatkan guru masih dipertahankan, muncul pertanyaan apakah kebijakan pengembangan kurikulum yang kurang melibatkan guru memang tepat bagi setiap guru pendidikan khusus. Di samping mendidik dan mengajar, guru juga didorong untuk terlibat dalam merancang kurikulum, yaitu dari kurikulum yang kaku menuju kurikulum yang lebih fleksibel dan fungsional yang menekankan pemecahan masalah dan komunikasi dalam berbagai bentuk.

Keberadaan kurikulum diibaratkan sebagai narasi kontrak sosial. Berbagai latar belakang hambatan yang dimiliki peserta didik berkebutuhan khusus amat kompleks. Pengembangan kurikulum akan lebih bermakna apabila dilakukan 
oleh guru yang memiliki pertimbangan idealisme, aspiratif, normatif, dan teknis yang khas. Dengan demikian, kurikulum yang dihasilkan dapat dijadikan wahana pengembangan berbagai aktivitas peserta didik berkebutuhan khusus itu sendiri secara kontekstual. Kerangka kerja seperti ini menjadi rujukan karena ada kepekaan, kemampuan mengidentifikasi, dan mencatat kebutuhan mereka. Laporan eksekutif UNICEF menekankan pentingnya pedagogi yang lebih inklusif, yang menggeser fokus dari gaya pembelajaran yang terpusat pada guru ke gaya pembelajaran ber-pusat pada peserta didik yang bisa merangkul berbagai gaya pembelajaran. Model seperti itu, menuntut guru memiliki pemahaman yang jelas tentang kurikulum (UNICEF, 2013). Laporan UNICEF tersebut memberi catatan bahwa untuk peserta didik berkebutuhan khusus memerlukan pendekatan yang fleksibel terhadap pengembangan kurikulum sehingga dapat mengembangkan kurikulum yang bisa merangkul berbagai gaya pembelajaran yang menggambarkan kebutuhan mereka.

Esensi kebutuhan peserta didik berkebutuhan khusus adalah keterampilan, pengetahuan praktis, kompetensi, karakter baik, dan pengalaman yang diperlukan untuk kemandirian secara luwes. Peserta didik berkebutuhan khusus yang mandiri merupakan keluaran pendidikan yang bertanggung jawab dalam kegiatan memerankan kehidupan. Oleh karena itu, kurikulum pendidikan khusus yang baik adalah kurikulum yang dikembangkan para guru peserta didik berkebutuhan khusus yang berorientasi akhir pada kebutuhan dan kesanggupan memenuhi harapan, keinginan, dan kebutuhan mereka. Semangat keterlibatan guru dalam pengembangan kurikulum pendidikan khusus perlu dibangkitkan. Dengan demikian, produk kurikulum peserta didik berkebutuhan khusus yang diimplementasikan sesuai dengan yang diharapkan.
Kurikulum untuk peserta didik berkebutuhan khusus telah banyak dirancang dengan isu-isu kesesuaian, seperti berisi pelbagai jenis pengetahuan untuk membantu, menemukan, dan mengembangkan kemampuan yang akan menjadikan mereka sanggup dalam menghadapi dinamika kehidupan yang akan datang. Namun, rancangan kurikulum tersebut selalu menyisakan sebuah pertanyaan, yaitu bagaimana sesungguhnya sebuah rancangan kurikulum supaya selaras dengan tuntutan siswa berkebutuhan khusus. Banyak pengalaman dari pengembang kurikulum dan tindakan dari para guru pendidikan khusus yang dimasukkan ke dalam perancangan kurikulum yang sesuai kebutuhan. Oleh karena itu, manakala kontemplasi dan refleksi dinamika pandangan guru dalam merancang kurikulum direkomendasikan, maka perannya juga harus dikuatkan. Satu dari rekomendasi yang dimaksud adalah terlibat dalam pengembangan kurikulum. Kerangka pikir pelibatan guru dalam merancang kurikulum selaras dengan temuan Doabler, Clarke, Fien, Baker, Kosty, dan Cary (2014) dalam penyelidikan awal terhadap rancangan kurikulum matematika Tier 2 untuk memperbaiki hasil belajar siswa kelas satu yang mengalami kesulitan belajar matematika. Hasil penelitian menemukan bukti awal bahwa penyusunan kurikulum dan evaluasi untuk mereka perlu ditata ulang berdasar pada teori perubahan yang ditentukan oleh guru.

Temuan Doabler tersebut memberi penguatan bahwa mekanisme perancangan kurikulum pendidikan khusus memerlukan gagasan-gagasan konkret yang konseptual dan komprehensif dari sudut pandang guru secara terbuka. Karena itu, mekanisme pengembangan kurikulum pendidikan khusus untuk peserta didik berkebutuhan khusus yang telah terjadi menarik untuk ditulis. Pertama, dengan kurikulum yang dirancang oleh guru pendidikan khusus akan memiliki derajat kesesuaian yang memenuhi syarat. Kedua, kurikulum yang dihasilkannya memiliki makna mendalam karena dikembangkan 
oleh orang-orang yang paham dengan hambatan mereka.

Pemahaman tentang hambatan peserta didik berkebutuhan khusus yang dituangkan ke dalam sebuah kurikulum memerlukan medium dan wacana kritis dari para guru tentang pencapaian dan keterlibatan peserta didik dalam melalui dan mengeksplorasi berbagai ragam aktivitas di seluruh kurikulum. Pada situasi global seperti saat ini, percepatan perubahan terjadi di segala sektor. Perancang kurikulum akan sulit menahan perkembangan ilmu pengetahuan, teknologi (terlebih teknologi informasi dan komunikasi), dan sosial-budaya yang tidak kontekstual. Menurut Plotner dan Dymond (2016) cakupan kurikulum sangat luas dan kompleks karena menyangkut arah kehidupan masyarakat ke masa depan. Dinamika perubahan dan perkembangan yang terjadi dalam kehidupan bermasyarakat, berbangsa, dan bernegara tidak terpisahkan dari perkembangan ilmu pengetahuan dan teknologi, senibudaya, globalisasi, dan digitalisasi. Perkembangan dan perubahan yang terjadi tersebut, menuntut adanya perbaikan dan penyelarasan dalam kurikulum pendidikan. Oleh karena itu, perwujudan sebuah rancangan kurikulum merupakan jawaban dari tuntutan kebutuhan masyarakat terhadap arah dan hasil dari pendidikan khusus.

Arah dan hasil pendidikan khusus yang diharapkan perlu dikonstruksi dan dirumuskan dalam konsep-konsep ideal secara sosial, mental, dan operasional dari pandangan dan gagasan guru di tingkat sekolah. Merujuk kajian Pusat Kurikulum dan Perbukuan (2011) pokok pikiran terkait program pembelajaran pendidikan khusus yang dirancang, memiliki dimensi yang cukup komprehensif, yakni kurikulum sebagai suatu: 1) ide/gagasan, 2) rencana tertulis, 3) kegiatan implementasi nyata, dan 4) rancangan yang perlu dievaluasi. Dengan demikian, fungsi utama kurikulum adalah sebagai acuan bagi terciptanya aktivitas pembelajaran di sekolah. Dengan fungsi seperti itu, maka kurikulum dapat dimaknai dan sekaligus sebagai acuan bagi:1) peserta didik dalam memperoleh bekal kemampuan hidup, 2) guru dalam melaksanakan pembelajaran, 3) kepala sekolah dan pengawas dalam melaksanakan supervisi, 4) orangtua dalam membimbing anak-anak belajar, dan 5) masyarakat dalam memberikan bantuan terhadap terselenggaranya pembelajaran di sekolah agar menghasilkan pendidikan yang lebih baik.

Dalam konteks kurikulum sebagai acuan pendidikan pada tingkat sekolah, dapat dimaknai kurikulum sebagai proses belajar peserta didik dan proses pengajaran yang memerlukan keterlibatan perancangan oleh guru. Kerangka pikir seperti itu selaras dengan hasil penelitian Figueiredo, Leite, dan Fernandes (2016) untuk dua negara Portugal dan Inggris dalam menanggapi keinginan badan-badan Eropa agar menciptakan proses evaluasi eksternal sekolah (school external evaluation-SEE) dalam upaya memperbaiki pendidikan dan kurikulumnya. Penelitian menyimpulkan:1) kurikulum dipahami sebagai proyek terbuka, 2) kerangka kerja SEE dari kedua negara membahas kurikulum dengan memusatkan perhatian pada peran guru sebagai pengembang kurikulum dan proses penyusunan kurikulum mereka, dan 3) kerangka kerja dari Portugal dan Inggris mengungkapkan keprihatinan atas lingkungan dan fungsi kelas yang ada.

Hasil penelitian Figueiredo tersebut memberi sinyal kuat bahwa keterlibatan guru SLB sebagai perancang kurikulum pendidikan khusus akan bisa menjaga harapan peserta didiknya. Strategi kerja pengembangan kurikulum seperti ini dapat memberi ruang luas kepada guru agar terlibat dalam menentukan arah perjalanan peserta didiknya. Isi kurikulum pendidikan khusus peserta didik berkebutuhan khusus yang baru akan lebih sesuai dengan penggunanya karena disusun oleh guru mereka.

Berdasarkan latar belakang di atas, dapat dirumuskan permasalahan utama, yakni: 
perancangan kurikulum dan asas kurikulum seperti apa ditinjau dari pandangan guru pendidikan khusus? Tujuan penelitian yaitu untuk mengkaji secara komprehensif tentang pandangan guru dalam keterlibatan pengembangan kurikulum pendidikan khusus pada konteks perancangan dan asasnya. Pola kerja seperti ini juga merujuk pandangan Berbiglia (2011), bahwa tujuan spesifiknya adalah untuk menggambarkan rancangan yang sesuai pada program pendidikan dengan mengadopsi kerangka konseptual kurikulum yang dirancang sepenuhnya oleh komunitas sekolah mereka, yakni guru SLB.

\section{METODE}

Penelitian ini memotret masalah pengembangan kurikulum pada konteks perancangan kurikulum dan asas kurikulum. Penelitian ini menggunakan suatu strategi studi kasus. Objek penelitian melibatkan sebanyak empat puluh tiga guru sekolah luar biasa dari delapan sekolah. Sekolah yakni: 1) SDLB ABCD, Kurnia Asih, Jombang, Jawa Timur; 2) SDLB Muhammadiyah, Jombang, Jawa Timur; 3) SLB C, Dian Grahita, Kemayoran, Jakarta Pusat; 4) SLB Negeri 5, Jakarta Barat; 5) SLB Negeri Baruga, Kota Kendari, Sulawesi Tenggara; dan 6) Sekolah Khusus Negeri I, Kota Kendari, Sulawesi Tenggara. Penelitian dilakukan pada bulan Agustus sampai dengan Desember 2016. Data dikumpulkan dengan menggunakan teknik diskusi kelompok terpumpun (FGD). Teknik analisis data menggunakan deskriptif kualitatif.

\section{HASIL DAN PEMBAHASAN}

Berikut deskripsi hasil penelitian dan pembahasan terkait pandangan guru dalam pengembangan kurikulum pendidikan khusus ditinjau dari dua dimensi, yakni perancangan kurikulum dan asas kurikulum.

\section{Perancangan Kurikulum}

Secara keseluruhan, berdasarkan hasil telaahan dari diskusi kelompok terpumpun terkait pandangan guru terhadap perancangan kurikulum pendidikan khusus ditemukan tiga temuan umum. Pertama, pandangan guru sekolah luar biasa antara satu dengan yang lainnya pada umumnya cenderung sepaham. Konsep perancangan kurikulum pendidikan khusus dengan melibatkan guru secara luas dapat dimaknai sebagai menghadirkan perspektif strategi kerja baru pada kebijakan. Strategi kerja kebijakan pengembangan kurikulum seperti itu selaras dengan hasil penelitian Leask (2013) bahwa internasionalisasi kurikulum memberikan tantangan dan peluang bagi staf akademik dan institusi. Oleh karena itu, bagian penting dari strategi kerja tersebut adalah pelibatan sekelompok tenaga kependidikan dan guru untuk memberikan tempat terkait pandangan dalam merancang kurikulum dan pembelajaran. Berdasarkan temuan penelitian Leask tersebut dapat dimaknai sebagai wadah kontribusi gagasan dan menjadikan pengalaman yang dimiliki guru berkontribusi pada perancangan kurikulum sesuai kebutuhan peserta didik.

Berdasarkan pandangan guru pada perancangan kurikulum pendidikan khusus di atas ada tiga temuan. Pertama, pemerintah sudah saatnya menata ulang kebijakan pengembangan kurikulum yang mampu melibatkan semua pemangku kepentingan pendidikan khusus. Dalam pelaksanaannya, upaya ini dapat dilakukan antara lain melalui strategi kerja model regional atau rayonisasi. Dengan demikian, diharapkan tidak ada lagi peluang mengecilkan tugas perancangan kurikulum pendidikan khusus karena semuanya bergerak dalam koridor yang sama. Momen ini tepat untuk menghasilkan sebuah rancangan kurikulum yang lebih bermakna yang meletakkan esensi pendidikan khusus sebagai praksis penyiapan kehidupan mereka.

Kedua, dari diskusi kelompok terpumpun dapat disintesiskan bahwa para guru umumnya memberi pandangan bahwa perancangan kurikulum untuk peserta didik berkebutuhan 
khusus harus mampu berperan pula mendorong pemerataan kesempatan pendidikan yang bermutu bagi mereka. Pandangan ini dapat dimaknai bahwa rancangan kurikulum yang dihasilkan harus memiliki kepekaan fleksibilitas yang sesuai dengan karakteristik masing-masing peserta didik. Ada dua hal yang bisa diambil pelajaran dari pandangan tersebut, yaitu kurikulum dan sistem persekolahan. Kurikulum harus dirancang terutama untuk membekali peserta didik berkebutuhan khusus menjadi warga negara yang baik. Sistem persekolahan pendidikan khusus, di manapun lembaga tersebut berada, harus mampu menjamin pemerataan kesempatan bagi mereka untuk bersekolah. Mereka tidak lagi merasa ditinggalkan. Dengan demikian, peningkatan akses dan mutu pendidikan merupakan keniscayaan. Begitu pula kurikulum yang ingin dirancang untuk mereka dalam sebuah dokumen juga harus mampu mendorong kesempatan yang sama kepada semua warga negara yang berkebutuhan khusus.

Warga negara yang berkebutuhan khusus dan tidak bisa mengikuti pendidikan di sekolah reguler harus dijamin dapat mengikuti kurikulum pendidikan khusus. Agar mereka memperoleh kesempatan mendapatkan pendidikan yang layak dan bermutu, harus dilayani dengan kurikulum khusus pula. Untuk merancang kurikulum peserta didik berkebutuhan khusus yang bermutu, salah satu parameternya harus diterjemahkan secara langsung dan esensial dari pikiran dan rancang pendidikan yang mengarahkan mereka memenuhi harapan dan aspirasi masyarakat. Kurikulum pendidikan khusus diibaratkan sebagai elemen strategis dalam sebuah program pendidikan dan proses perancangannya pun memerlukan pemikiran yang strategis dari pandangan guru. Pemikiran strategis tersebut menjawab tiga masalah utama yang direkomendasikan Collins dan Yates (2009), yakni: 1) memprioritaskan keadilan sosial, 2) fokus pada perkembangan peserta didik secara individual, dan 3) pencarian kesamaan ketentuan kurikulum dengan alternatif mata pelajaran akademis sebagai landasan utamanya.

Pandangan yang diungkapkan para guru pada temuan umum kedua tersebut banyak ditemui dalam beberapa isu pembelajaran yang kait-mengkait. Hal ini menegaskan pada urgensi menjawab tantangan perancangan kurikulum bagi peserta didik berkebutuhan khusus guna berhasilnya lulusan berkebutuhan khusus. Selain mutu, yang sangat mendesak untuk diwujudkan adalah muatan utama bahan kajian perancangan kurikulum untuk kebutuhan mereka. Esensinya, bukanlah model perancangannya, melainkan kelebihan apa yang dimuat dari kurikulum dan hal pokok apa yang perlu ada dalam rancangan kurikulum.

Ketiga, para guru umumnya berpandangan agar mereka dilibatkan secara aktif, interaktif, dan produktif dalam bentuk kegiatan workshop perancangan kurikulum, mulai dari pembahasan ide, filosofi, desain, dokumen, implementasi, dan evaluasi. Pola kerja semacam itu menyisakan sebuah pertanyaan bagaimana alam pikiran pembuat kebijakan pendidikan khusus terhadap model seperti itu? Apakah mereka menangkap makna sebuah perancangan kurikulum yang lebih sederhana, yang lebih sesuai atau yang lain? Dengan rancangan kurikulum yang lebih sederhana, dapat mendorong sebuah kebijakan yang penting karena memiliki tingkat keluwesan bagi peserta didik berkebutuhan khusus dalam mengikuti pembelajaran. Dalam kenyataannya, peserta didik berkebutuhan khusus memiliki aspek pemahaman yang kompleks dan rumit dalam mengikuti pembelajaran. Dengan kondisi seperti itu, perancangan kurikulum yang peka terhadap keluwesan menjadi tuntutannya.

Dalam arti yang hakiki,kurikulum pendidikan khusus sebenarnya terletak pada diri peserta didik berkebutuhan khusus itu sendiri. Rancangan kurikulum tersebut dapat berupa program untuk meningkatkan kemampuan akademik, nonakademik, maupun program 
kebutuhan khusus sehingga mampu mereduksi hambatan yang diakibatkan oleh kekhususan mereka. Oleh karena itu, kurikulum harus dirancang sederhana, mudah diterapkan, dan sesuai karakteristik peserta didik. Dalam konteks perancangan kurikulum sederhana, tidak semua guru harus berpikiran sama, tetapi bersamasama berpikir tentang peserta didik berkebutuhan khusus yang berpotensi, beragam, berbeda, dan unik. Potensi tersebut menunggu komitmen semua pemangku kepentingan untuk dimanifestasikan pada kemampuan memahami, mencerna, dan menerjemahkan pengetahuanpengetahuan praktis, dan kemudian diterjemahkan ke dalam tindakan-tindakan yang juga praktis.

Dari tiga temuan umum di atas, perlu dipikirkan kebijakan seperti apa yang harus dikembangkan oleh pengembang kurikulum di Kemendikbud di masa yang akan datang. Pandangan para guru tersebut menjadi bahan perenungan. Peserta didik berkebutuhan khusus pada umumnya memiliki kelainan fisik, emosional, mental, sosial, dan hambatan lainnya dalam koridor konsepsi yang bersifat multidimensi dan secara alamiah guru yang lebih mengetahui. Pada kenyataannya, pada setiap jenis ketunaan tertentu maupun antarketunaan, mereka umumnya juga memiliki hambatan dan kemampuan yang bervariasi. Bervariasinya hambatan dan kemampuan disebut dengan istilah tuna ganda. Berkaitan dengan hambatan tersebut, guru umumnya memberikan pandangan bahwa kurikulum yang dirancang di samping sederhana juga harus mampu mengayomi, tidak mengabaikan serta mewadahi strategi kontekstualisasi keragamam tersebut. Rancangan kurikulum yang peka dengan hal itu, pada peserta didik akan memperoleh nilai kepastian, kasih sayang, rasa aman, kenyamanan, dan berkeadilan sehingga mereka tidak merasa ditelantarkan.

Dengan berbagai pandangan guru sebagaimana di atas, rancangan kurikulum pendidikan khusus yang dihasilkan menjadi sarat makna karena mewadahi kepentingan dan sesuai dengan keadaan, kebutuhan, dan karakteristik peserta didik yang juga berkebutuhan khusus. Sejumlah pandangan guru yang disampaikan membawa pada kesamaan pandangan dari Lamb dan Branson (2015) dalam makalahnya tentang pendidikan perubahan kepemimpinan melalui lensa teori, yang mereka sebut zona baru. Lamb dan Branson merekomendasikan agar peserta didik berhasil dalam matematika disarankan mengubah perancangan kurikulum di sekitar mereka. Pandangan ini memberi makna bahwa perancangan kurikulum yang sesuai dengan konteks latar belakang peserta didik berkebutuhan khusus tentu menjadi bagian strategi yang melayani, yang dicintai, dan yang dicari. Secara sederhana, instrumen kebijakan tersebut mampu memahami dan memandu realitas.

Tindakan guru yang mengekspresikan kebijakan dalam workshop perancangan kurikulum dan sejumlah kegiatan lainnya serta semangat guru berani meniru yang baik dari apa yang tumbuh pada diri peserta didik di sekolah menjadi konsep rancangan kurikulum. Konsep rancangan selanjutnya diperkaya dengan sentuhan kecakapan yang sistematis dengan ilmu pengetahuan, teknologi, seni, dan budaya yang sesuai dengan lingkungan peserta didiknya. Semangat seperti itulah yang mestinya diupayakan secara terus-menerus dan dilaksanakan oleh tim pengembang kurikulum pendidikan khusus dalam membantu pendidikan bagi sebagian masyarakat yang tidak bisa mengikuti program pendidikan secara normal. Dalam arti, rancangan kurikulum yang dapat dijadikan sebagai kebijakan yang mampu mewadahi, menjalin, dan mengikat realitas konteks pada sebuah konsepsi yang bersifat multidimensi peserta didik.

Perancangan kurikulum yang harus dipikirkan bagi sebagian masyarakat yang tidak bisa sekolah secara normal karena memiliki beragam hambatan dan ketunaan adalah bagaimana agar 
mereka setelah mengikuti pendidikan mampu menjalani kehidupan sehingga tidak menjadi beban orang lain. Arah rancangan kurikulum untuk peserta didik berkebutuhan khusus hendaknya menuju pada mereka belajar untuk kehidupan. Perancangan kurikulum senantiasa mentransformasikan diri untuk mengembangkan melalui pendekatan dan penerapan model-model pembelajaran yang dapat meningkatkan antara lain jiwa kewirausahaan, kemandirian, produktivitas, kreativitas sebagai bekal dasar untuk hidup di masyarakat. Dengan demikian, mereka yang memiliki hambatan tertentu dapat didorong agar memiliki keyakinan menjadi bagian dari bangsa yang mandiri, maju, sejahtera, dan berdaya saing tinggi.

Dalam perkembangannya, keyakinan peserta didik berkebutuhan khusus terhadap relevansi dan aktualisasi melalui sebuah rancangan kurikulum bisa bertambah dan berkurang seiring arus pengaruh dan dinamika perubahan secara internal dan eksternal di sekolah maupun di rumah. Keyakinan akan senantiasa menguat manakala proses pendidikan mampu membantu peserta didik berkebutuhan khusus memahami kekhasan potensi dirinya, sekaligus kemampuan menempatkan diri dalam konteks keseimbangan dan keberlangsungan kehidupan bermutu. Sementara itu, penurunan keyakinan bisa terjadi manakala terdapat kesenjangan antara idealitas rancangan kurikulum dan realitas output produk kurikulum dalam kehidupan.

Pada diskusi kelompok terpimpin, guru umumnya juga memberikan pandangan bahwa tidak ada bangsa maju dan berdaya saing tinggi tanpa didukung pendidikan yang baik dengan kurikulum yang dirancang futuristik serta pembelajaran sesuai kebutuhan peserta didiknya. Pembangunan sumber daya manusia yang cakap, cerdas, kreatif, dan kompeten harus disiapkan dengan perancangan kurikulum yang sesuai tuntutan zaman dan kebutuhan kecakapan masyarakat masa depan. Untuk itu, kurikulum pendidikan khusus yang dirancang beserta dokumen pendukungnya tidak hanya abstraksi, tetapi juga dilengkapi berbagai contoh baik, pilihan, dan arah dengan fokus utama pada daya guna dan hasil guna. Hal tersebut akan berdampak pada peningkatan mutu peserta didik berkebutuhan khusus yang menjalankan tugasnya. Kemampuan menjalankan tugas dengan hasil baik selain bermuatan pengetahuan praktis, keterampilan, kekokohan kompetensi juga bermuatan sistem nilai kualitas karakter yang memandu sikap dan perilaku. Sistem nilai karakter yang dimaksud di antaranya keagamaan, moral, etika, disiplin, tanggung jawab, kinerja, sosial, budaya, kearifan lokal, politis, dan lainnya.

Pijakan dan strategi kerja proses perancangan kurikulum amat tepat apabila mampu melibatkan berbagai pemangku kepentingan mulai dari birokrat pembuat kebijakan, praktisi, pengguna lulusan, ahli, guru hingga pemerhati pendidikan. Pelibatan berbagai pemangku kepentingan perancangan kurikulum, selaras dengan hasil penelitian Richardson (2005) yang menyimpulkan bahwa karakteristik demografis orang yang merespon survei berbeda dari mereka yang tidak menanggapi dalam hal usia dan kelas sosial. Hasil penelitian Richardson (2005) juga dapat dimaknai bahwa perancangan kurikulum pendidikan khusus akan memiliki botot nilai yang berdaya serta memandirikan manakala mampu memberdayakan sumber daya pemangku kepentingan pelaksana pendidikan secara optimal. Dua pijakan ini saling melengkapi karena dapat diasumsikan bahwa guru yang memberikan pandangan terkait perancangan kurikulum melalui $F G D$ memiliki umpan balik yang berbeda secara sistematis dari mereka yang tidak menanggapi.

Pengembang kurikulum pusat dapat memelihara potensi kekayaan pandangan para guru dengan pemberian peran sebagai pengembang kurikulum di daerahnya. Peran guru SLB dalam perancangan kurikulum pendidikan 
khusus adalah penting karena mereka mampu mengenali dan menemukan keberagaman peserta didik berkebutuhan khusus yang ada di sekolah. Melalui mekanisme sistem pelibatan yang direncanakan dengan baik, akan menghasilkan kualitas rancangan kurikulum masa depan sesuai kebutuhan peserta didik berkebutuhan khusus. Kualitas rancangan kurikulum menentukan pula kualitas keluaran peserta didik. Proses ini merupakan idealisme perancangan kurikulum pendidikan sebagai basis untuk berinvestasi di bidang pembangunan sumber daya manusia.

Perancangan kurikulum yang dicetuskan para guru dapat menjadi sumber di dalamnya tercantum muatan-muatan bahan kajian, seperti pengetahuan praktis, keterampilan, kualitas karakter, dan kemampuan dengan harapan peserta didik berkebutuhan khusus memiliki etos hidup yang baik. Guru mampu memahami masalah-masalah peserta didik berkebutuhan khusus yang kompleks dan mampu menemukan pemecahan atas masalahmasalah yang kompleks itu tanpa menimbulkan masalah baru. Rancangan kurikulum yang diarahkan tidak hanya pada kebutuhan peserta didik berkebutuhan khusus, melainkan diharapkan mereka juga mampu menguasai ilmu pengetahuan, memiliki sikap, memiliki perilaku, dan kecakapan hidup.

Miller (2011) mengatakan ketika guru memahami "gaya kurikulum mereka sendiri", mereka dapat membuat keputusan secara sadar tentang menggabungkan gaya lain ke dalam praktik mereka, yaitu tentang realita. Hal ini dapat diartikan bahwa manakala perancangan kurikulum sebagai kebijakan strategis merupakan hasil karya dari pandangan para guru, maka kebijakan tersebut dapat dimaknai sebagai memahami dan memandu realitas. Ia menjadi instrumen simbolis, yakni cara berpikir dibentuk oleh beragam metode, teknik, dan pengalaman yang digali dari para guru. Dengan demikian, karya kurikulum dapat diterima para guru dalam komunitas mereka.

Penelitian Gerrard, et al. (2013) terkait praktik dan tata kelola pendidikan menginformasikan bahwa di bawah naungan 'Revolusi Pendidikan', pemerintah telah memberikan ruang lingkup yang luas untuk mengkaji terhadap perubahan sistem dan praktik tingkat sekolah termasuk dalam reformasi kurikulum berskala besar. Temuan penelitian ini memberi gambaran bahwa perancangan kurikulum sebaiknya dilakukan dengan cara memberi kesempatan kepada semua pemangku kepentingan pendidikan bukan sekadar ornamen, melainkan substansi pembelajaran. Dengan memberikan ruang kepada guru untuk mempelajari muatanmuatan yang relevan bagi peserta didik berkebutuhan khusus dari lingkungan sekitar, maka rancangan kurikulum itu memiliki derajat adekuat. Dengan demikian, hasil perancangan kurikulum akhirnya dapat menopang tersusunnya instrumen penting pendidikan.

Arah kurikulum pendidikan khusus yang dirancang harus mampu mengintervensi dan bersesuaian dengan kebutuhan akademik maupun nonakademik peserta didik berkebutuhan khusus sebagai penyiapan untuk meningkatkan mutu kehidupan secara bertanggung jawab. Intervensi yang dimaksud adalah perancangan kurikulum direncanakan dengan pendekatan partisipatif, humanistik, dan konstruktif yang dilakukan dengan pendekatan kontekstual dan berpusat pada peserta didik. Hal ini mengindikasikan bahwa guru sebagai penggagas pandangan perancangan kurikulum memiliki kepekaan dan kemampuan mengidentifikasi, menemukan, dan mencatat kebutuhan peserta didik. Kebutuhan penyandang suatu ketunaan berbeda dengan kebutuhan penyandang ketunaan lainnya.

Dengan memberi ruang yang luas perancangan kurikulum yang dikembangkan harus memiliki ciri kesesuaian dengan konteks sosial 
budaya yang diwarnai oleh nilai lain, seperti nilai-nilai kearifan lokal, norma, dan etika. Pemikiran seperti itu akan mengarahkan peserta didik berkebutuhan khusus memiliki kemampuan berupa sikap dan perilaku berkehidupan bersama. Perancangan kurikulum pendidikan di alam Indonesia sesungguhnya telah memiliki suatu konsepsi bersama menyangkut nilai-nilai dan moral bagi peserta didik, yakni tujuan pendidikan nasional. Dalam tujuan tersebut telah memiliki landasan keyakinan normatif dan preskriptif yang jelas dan visioner sebagai fundamen etik kehidupan bermasyarakat, berbangsa, dan bernegara. Karenanya, rancangan kurikulum yang bersifat nasional dan lokal turut menjadi warna pertimbangan guru. Pada konteks lain, pandangan guru dalam perancangan kurikulum juga harus senantiasa mempertimbangkan kebutuhan bangsa, yaitu kecakapan dan kualitas karakter bangsa Indonesia. Pada domain pengimplementasian, pembelajarannya pun harus sarat dengan sentuhan penguatan kecakapan dan internalisasi nilai-nilai yang dirancangkan.

Pada saat $F G D$ sebagian besar guru juga menyatakan bahwa perancangan kurikulum hendaknya mampu memberikan dorongan semangat peserta didik berkebutuhan khusus agar tidak putus asa dan tidak tergantung kepada orang lain. Pembelajaran peserta didik berkebutuhan khusus diberi kepercayaan dan akses yang luas ke berbagai bidang agar mereka berdaya, percaya diri, serta mandiri. Mereka mampu berkontribusi terhadap pembangunan, bahkan turut serta menciptakan lapangan pekerjaan, asalkan diberi kesempatan dan waktu. Hasil penelitian Mogilner, Chance, dan Norton (2012) tentang pemberian waktu, menemukan bahwa umumnya seseorang tidak memiliki cukup waktu. Dengan memberikan sebagian waktu peserta didik akan lebih mau berkomitmen di masa depan sehingga rasa kesejahteraan waktu subjektif mereka dapat meningkat. Temuan ini memberi arti jika perancangan kurikulum dan pembelajaran peserta didik berkebutuhan khusus yang sarat dengan beragam muatan diberikan peluang terbuka dan cukup waktu untuk berlatih bekerja, berkarya, dan memasuki kehidupan maka mereka akan makin berdaya.

Rancangan kurikulum juga harus mampu mendorong pemberian sarana kepada peserta didik berkebutuhan khusus untuk mengenali dan mengembangkan kebudayaan. Kebudayaan sebagai sistem nilai, sistem pengetahuan, dan sistem perilaku ini secara keseluruhan membentuk lingkungan sosial yang dapat menentukan apakah pengetahuan praktis yang dimilikinya, keterampilan, kompetensi, karakter, praksis literasi serta budaya bersekolah dapat berkembang menjadi lebih baik atau lebih buruk. Menjadi lebih baik merupakan tujuan utama dari sebuah rancangan kurikulum. Kebaikan sebagai dampak dari pendidikan akan memunculkan bibit unggul bagi warga bangsa. Bibit-bibit unggul individu harus tumbuh melalui sebuah rancangan kurikulum yang bermakna.

\section{Asas-Asas Kurikulum}

Eksplorasi pandangan para guru SLB melalui FGD memiliki dampak pada hasil belajar peserta didik berkebutuhan khusus yang lebih baik. Setiap kegiatan di sekolah melalui kurikulum merupakan suatu pengalaman yang berkaitan dengan banyak hal lain di sekitarnya. Oleh karena itu, menurut sebagian besar pandangan guru, kurikulum pendidikan khusus harus dikembangkan dengan menajamkan beragam asas secara kontekstual dan menarasikan aspek lain sesuai kebutuhan peserta didik yang memiliki beragam hambatan.

Asas kurikulum dalam konteks penelitian ini dimaknai sebagai prinsip dasar yang menjadi acuan dari sudut pandang guru dalam berpikir mengambil keputusan terkait pengembangan kurikulum pendidikan khusus. Cara pandang guru dalam merepresentasikan gagasan-gagasan berkait asas-asas pengembangan kurikulum 
dengan mendasarkan pada paradigma pengalaman yang dimilikinya. Paradigma tersebut kemudian menimbulkan keyakinan. Keyakinan akan menumbuhkan cara guru melihat asasasas kurikulum sebagai kebaikan. Sebagai kebaikan, dari FGD disintesiskan ke dalam banyak temuan pandangan baru sebagai asasasas kurikulum. Dimaknai sebagai pandangan baru karena asas-asas yang dimaksud adalah di luar kelaziman yang selama ini dirujuk dalam mengembangkan kurikulum, seperti asas filosofis, asas psikologis, asas sosiologis, asas organisatoris, dan perkembangan ilmu pengetahuan dan teknologi (Hamalik, 2007; Zaini, 2009; Nasution, 2014; Moore, 2015).

Lima asas yang dapat disimpulkan dari $F G D$ dengan para guru SLB mengenai pengembangan kurikulum adalah: 1) keluwesan, 2) fungsional, 3) kemandirian, 4) literasi, dan 5) kejuruan. Dengan lima asas pengembangan kurikulum yang mendasar ini, para guru mengajak berbagai pihak pemangku kepentingan untuk belajar dan menengok peserta didik berkebutuhan khusus dan sekaligus menghayati hidup bersama dengan mereka serta menghargai pemikiran mereka. Hasil kajian Cochran-Smith dan Dudley-Marling (2012) mengungkapkan sangat penting untuk menemukan ruang kolaboratif yang memiliki potensi untuk menyatukan keragaman masyarakat dan membangun sinergi baru dalam pendidikan. Hasil kajian ini memberi penguatan bahwa mengarahkan berbagai hambatan yang dimiliki peserta didik berkebutuhan khusus melalui kurikulum dengan asas-asas tertentu hasil dari pandangan para guru mereka menjadi penting. Siuty, Leko, dan Knackstedt (2016) menggunakan kerangka teori dari pembuatan keputusan, seperti memfasilitasi pengambilan keputusan guru yang telah banyak membuat keputusan setiap hari, bahwa ada hubungan dua arah antara kurikulum dan keyakinan mereka.

Kegiatan diskusi kelompok terpumpun dijiwai dengan semangat kolaboratif bagi berbagai pemangku kepentingan pendidikan khusus. Dalam kolaboratif terjadi interaksi antaranggota tim untuk saling berkomunikasi, mempengaruhi, mendengar, menghargai, kompromi, bernegosiasi yang merupakan kecakapan yang dibutuhkan dalam kehidupan. Kecakapan tersebut hendaknya juga termanifestasikan dalam kurikulum pendidikan khusus. Schleicher (2012) mengemukakan bahwa kolaborasi merupakan salah satu kecakapan penting di abad 21 , selain kreativitas dan inovasi, berpikir kritis (termasuk di dalamnya pemecahan masalah), dan komunikasi. Dalam kolaborasi, keterampilan sosial, peduli sosial, etika sosial, dan kepedulian terhadap lingkungan menjadi pelengkapnya.

Kristalisasi pandangan guru hasil dari kolaborasi guru yang dipaparkan di atas, dapat diartikan sebagai kreasi khas kurikulum pendidikan khusus yang dilaksanakan para guru SLB. Hasil kreasi khas tersebut dapat dimaknai sebagai upaya kebermaknaan dalam kerangka pikir terbuka pada pemberdayaan guru dengan pengembang kurikulum pusat. Kesempatan tersebut merupakan tanggapan atas peran birokrat pengembang kurikulum yang selama ini dinilai cenderung terstruktur, kaku, dan kurang menyentuh keberpihakan. Ketidakmudahan strategi, alur, prosedur, dan proses pengembangan suatu kurikulum juga memperoleh penguatan hasil kajian Chin, May, Sullivan-Chin, dan Woodrick (2014). Dinamika interpersonal sebuah departemen seringkali memang merupakan rintangan pertama dan paling sulit untuk diatasi dalam menerima pemikiran orang lain.

Strategi kerja dengan melibatkan para guru secara luas dapat diartikan sebagai terobosan dalam pengembangan kurikulum pendidikan khusus. Strategi kerja yang ditempuh, ternyata mampu menginspirasi perspektif pandangan para guru dan sekaligus merupakan sintesis dari sebuah penggalian untuk merancang kurikulum yang andal. Keterandalan sebuah kurikulum merupakan satu hal yang diamanatkan Peraturan 
Presiden Republik Indonesia Nomor 2 Tahun 2015 tentang Rencana Pembangunan Jangka Menengah Nasional 2015-2019 yang menjelaskan bahwa sasaran pemba-ngunan di bidang pendidikan antara lain tersedianya kurikulum yang andal (Badan Perencana Pembangunan Nasional, 2015). Dengan demikian, muatanmuatan yang disusun dalam kurikulum pendidikan khusus selain mendasarkan pada asas-asas kurikulum walau masih bersifat gagasan, juga harus berfokus pada potensi peserta didik yang ingin dikembangkan.

\section{Asas Keluwesan}

Dari diskusi kelompok terpumpun, guru umumnya mengutarakan bahwa pengembangan kurikulum pendidikan khusus hendaknya berprinsip pada asas keluwesan. Dalam arti, konten disusun secara luwes sesuai karakteristik peserta didik berkebutuhan khusus. Dengan demikian, dokumen kurikulum selain berorientasi pada pemberdayaan peserta didik juga menjadi orientasi dan tujuan utama dari pendidikan khusus itu sendiri. Berkaitan dengan kristalisasi orientasi asas dan tujuan program pendidikan tersebut, Schoenfeld (2016) mencirikan kurikulum yang dikonseptualisasikan yaitu yang mampu menjalankan fungsi restoratifnya sebagai program pendidikan yang khusus untuk membangun narasi tentang peserta didik berkebutuhan khusus. Kurikulum pendidikan khusus untuk peserta didik berkebutuhan khusus tidak boleh distandarkan. Gagasan dalam konteks tidak distandarkan tersebut dikuatkan oleh Bouck dan Kulkarni (2009) dalam studinya tentang cara terbaik untuk mengajar matematika bagi peserta didik dengan ketidakmampuan belajar mengungkapkan bahwa peserta didik dengan ketidakmampuan belajar tidak diuntungkan dengan menerima kurikulum matematika yang distandarkan.

Kurikulum yang merupakan rencana yang dibuat untuk membimbing dan mengarahkan peserta didik berkebutuhan khusus belajar di sekolah sebaiknya disusun secara luwes dan disajikan dalam bentuk dokumen. Kurikulum sebagai suatu bentuk dokumen harus memberikan petunjuk yang cukup rinci mengenai berbagai hal yang mencakup pertumbuhan secara emosional, sosial, fisik, dan akademik. Hollins (2011) dalam kajiannya terhadap penyiapan calon pengajar yang berkualitas mengungkapkan bahwa sikap filosofis mempengaruhi desain pengalaman belajar, pembingkaian kurikulum, dan konteks sosial di dalam kelas. Bingkai kurikulum dibuat selaras dengan konteks sosial peserta didik berkebutuhan khusus dalam bentuk rencana program pendidikan yang luwes agar bisa memberikan dorongan semangat belajar bagi penggunanya.

Pada konteks lain, program pendidikan khusus juga merupakan jalan untuk membangun budaya dan peradaban. Dengan demikian, asas pengembangan kurikulum pendidikan khusus hendaknya memiliki kelenturan pembentukan adab dan budaya yang melaluinya. Pada sisi yang lain, kurikulum pendidikan khusus ditujukan untuk mengantisipasi kebutuhan mereka baik pada saat sekarang maupun di masa yang akan datang. Sebagai rambu-rambu, kehadiran kurikulum seyogianya memuat materi yang luwes dan mudah diajarkan, dipelajari, dan diukur pencapaiannya. Konsep berbagai kemudahan itu diperkuat oleh Pugach dan Blanton (2012) dalam studi eksplorasi terhadap kurikulum program pendidikan guru. Perhatian terhadap kecacatan lebih menonjol daripada memperhatikan penanda identitas sosial lainnya seperti ras, kelas, budaya, atau bahasa. Temuan ini menyiratkan bahwa peserta didik berkebutuhan khusus memerlukan kurikulum yang lebih luwes daripada sekadar konten pembelajaran yang terstruktur kaku.

Kurikulum bukan sekadar daftar materi pelajaran yang dipindahkan dalam diri peserta didik. Kurikulum merupakan sebuah rancangan yang luwes yang memberikan ruang seluas- 
luasnya bagi tumbuhkembangnya keadaban dan berkembangnya potensi diri. Kondisi diri peserta didik berkebutuhan khusus umumnya sangat beragam, baik secara akademik maupun nonakademik. Pengembangan kurikulum dengan paradigma asas keluwesan sebagai acuan diharapkan dapat diadaptasi oleh guru dengan menambah atau mengurangi keluasan dan kedalaman materi, atau menggantinya dengan materi yang lebih sesuai bagi peserta didik. Kata "berkebutuhan khusus" menjadi dasar pijakan dalam melihat apa yang menjadi masalah dan kebutuhan peserta didik dan bukan pada "label" hambatan yang ada padanya. Di saat guru terlibat mengembangkan kurikulum, mereka berpandangan bahwa setiap peserta didik berkebutuhan khusus memiliki potensi, ragam, berbeda, dan unik. Karakteristik ini dijadikan panduan bagaimana asas yang lebih tepat dalam kurikulum agar memenuhi kebutuhan mereka.

Asas keluwesan akan menuntun guru dalam konsep diversifikasi kurikulum. Kerangka pikir diversifikasi ini amat berguna untuk mengatasi hambatan dan mengoptimalkan potensi empat area fungsi, yakni area fungsi belajar (learning), sosial emosi (socio-emotional), komunikasi (communication), dan neuromotor. Dengan kurikulum yang didiversifikasi, upaya-upaya pemberian layanan pendidikan terhadap peserta didik berkebutuhan khusus secara optimal bisa difokuskan pada potensi-potensi yang dapat dikembangkan melalui pengamatan guru secara berkesinambungan dan sistematik dalam proses identifikasi dan asesmen. Melalui identifikasi dan asesmen diharapkan guru dapat memberikan layanan pendidikan yang baik secara luwes dan sesuai dengan kondisi dan karakteristik mereka sehingga potensi dirinya berkembang secara optimal.

Dengan kurikulum yang mewadahi kebutuhan dan karakteristik peserta didik berkebutuhan khusus secara luwes, variasi konteks kelainan dan hambatan-hambatan yang dimiliki dan lingkungan yang ada bisa dijawab melalui kurikulum. Dalam arti, bervariasi sesuai konteks, sesuai kebutuhan mereka karena memiliki kelainan fisik, emosional, mental, sosial, serta hambatan intelektual. Bahkan, kadangkala masih disertai dengan penyandang down syndrome. Dengan asas pengembangan kurikulum yang luwes seperti itu, pada akhirnya akan mengungkit potensi sumber daya yang ada. Para guru percaya setiap peserta didik berkebutuhan khusus memiliki sesuatu untuk disampaikan dan mereka berhak mendapat kesempatan untuk memperlihatkan potensi terbesar mereka sehingga pelaksanaan implementasi kurikulum dinilai lebih bersahabat, inklusif, dan adil.

\section{Asas Fungsional}

Dari FGD terungkap bahwa masalah-masalah yang dihadapi peserta didik berkebutuhan khusus umumnya adalah masalah bimbingan, pendampingan, perhatian dan kasih sayang, layanan pendidikan, putus harapan, dan pencarian alternatif pendidikan di luar rumah. Problematika sosial seperti itu membutuhkan pemecahan khusus dari sebuah kurikulum yang dikembangkan dengan prinsip dasar yang bersifat fungsional. Dalam artian, jabaran konten maupun strukturnya memiliki landasan asas fungsi yang kuat secara filosofis, pedagogis, dan teoritik. Dengan menempatkan pandangan para guru pada asas fungsional dalam mengarahkan pengembangan kurikulum, pada akhirnya program tersebut dapat menjawab tantangan dan kebutuhan peserta didik berkebutuhan khusus.

Azas utama tantangan dan kebutuhan peserta didik berkebutuhan khusus adalah keadaban dan pembudayaan untuk kehidupan. Walau mereka memiliki berbagai hambatan fisik maupun nonfisik, menjadi manusia yang beradab dan berbudaya merupakan fungsi utamanya. Sudut pandang berpikir guru tersebut sesuai dengan dari hasil penelaahan Hamilton, McFarland, dan Mirchandani (2000) dalam 
konteks pengintegrasian kurikulum bisnis. Hamilton, et al. mensintesiskan bahwa kerangka kerja penyusunan terdiri atas dua dimensi utama, yaitu konteks kurikulum dan pendekatan pedagogis dengan fokus pada serangkaian pendekatan integratif yang konsisten dengan preferensi lokal mengenai tujuan dan kendala. Hasil penelaahan ini memberi makna bahwa jika kurikulum disusun dengan mempertimbangkan fungsinya, maka dokumen tersebut akan mengemban misi hidup yang cukup signifikan. Artinya, selain harus kontekstual dengan realitas, kurikulum juga harus mengarahkan pada satu kesatuan fungsi yang didasarkan pada kenyataan diri peserta didik berkebutuhan khusus.

Di samping agar kurikulum memberikan pernyataan yang bermakna menghadapi beragam hambatan peserta didik berkebutuhan khusus, para guru juga memberikan pandangan bahwa dokumen yang akan dikembangkan hendaknya juga mampu menggarap proses mental peserta didik. Mental yang dimaksud berupa cerapan indra, emosi, pemikiran sebagai fungsi dari organisme biologis yang berkelainan dalam penyesuaiannya terhadap lingkungan serta pengendalian lingkungan yang pada gilirannya memberikan kesadaran kehidupan. Dengan asas fungsional seperti itu fungsi mengembangkan diri kemampuan peserta didik di tengah masyarakat dengan bekal pengetahuan praktis, keterampilan, kemampuan, dan keahlian yang dimiliki diharapkan mampu memecahkan masalah di tengah lingkungan yang terus berubah dan penuh kompetisi ketat. Pandangan gagasan guru seperti itu selaras dengan kajian Lambert (2013) mengenai geografi dan pendidikan yang menyatakan bahwa krisis ekonomi dan lingkungan yang dihadapi umat manusia saat ini memerlukan respon pendidikan dengan rancangannya berupa 'kurikulum kelangsungan hidup'. Tesis dari dua kerangka pikir seperti itu dapat dimaknai sebagai mengantarkan pada pengembangan kurikulum yang harus berfungsi memecahkan masalah hidup peserta didik berkebutuhan khusus dalam memasuki kehidupan.

Lokus kurikulum adalah untuk kehidupan. Hal ini berarti fungsi dokumen tersebut hendaknya diorientasikan pada penumbuhan kapasitas peserta didik untuk mengembangkan diri dan mengatasi masalah-masalah hidup yang akan dihadapinya. Penelitian Nuttall (2016) tentang perancangan dan implementasi kurikulum dalam studi kasus sekolah dasar perkotaan di utara Inggris, sebagai tanggapan terhadap diperkenalkannya Kurikulum Nasional yang direvisi pada bulan September 2014, antara lain menyarankan agar kurikulum bergerak menuju 'arsitektur terbuka' yang lebih banyak meningkatkan keterlibatan peserta didik belajar dengan mengurangi pengajaran untuk diuji dan menciptakan pengalaman belajar yang responsif dan nyata secara fungsional. Temuan penelitian ini dapat diartikan bahwa asas pengembangan kurikulum harus sarat dengan paradigma belajar aktif sehingga mampu mendorong pengalaman belajar peserta didik berkebutuhan khusus dalam meningkatkan keterampilan, mengasah kepekaan, dan tanggung jawab sosial. Dengan demikian, hasil kurikulum yang disusun memiliki bobot fungsi yang signifikan dalam mengawal pendewasaan mereka.

Dengan prinsip belajar aktif tersebut pengembangan kurikulum pendidikan khusus diharapkan memiliki muatan kepekaaan terhadap keterampilan hidup peserta didik berkebutuhan khusus, dengan berorientasi pada konteks lingkungan sekitar. Alwell dan Cobb (2009) dalam studi intervensi terhadap 482 pemuda, yang sebagian besar memiliki label kecacatan sedang hingga keterbelakangan mental berat mengungkapkan bahwa kurikulum yang amat dibutuhkan bagi mereka adalah bekal fungsional atau keterampilan hidup, sehingga dapat mempromosikan hasil transisi positif. Temuan ini dapat dimaknai bahwa salah satu asas pengembangan kurikulum untuk peserta didik 
berkebutuhan khusus adalah memandu intervensi muatan fungsional yang mampu mempromosikan kepercayaan diri peserta didik karena mereka memiliki masalah multidimensional, tidak bisa dilihat dari satu aspek saja. Paling tidak hak pendidikan mereka terpenuhi melalui kurikulum yang dikembangkan dengan prinsip pada fungional.

Kurikulum fungsional hasilnya memiliki peran yang tidak langsung dan dikontekstualisasikan dengan potensi sumber daya peserta didik berkebutuhan khusus yang ada dan secara praksis bisa diharapkan mengatasi masalah. Kehidupan mereka dapat ditumbuhkembangkan secara optimal melalui kurikulum dengan perlakuan pemecahan masalah untuk melatih kehidupan. Dengan demikian, fragmentasi sosial yang belakangan muncul di komunitas guru SLB menjadi momentum untuk mengingat kembali semangat pengembangan kurikulum yang fungsional untuk anak didiknya. Hunt, McDonnell, dan Crockett (2012) dalam kajiannya mengenai kurikulum pendidikan umum dan ekologi menyarankan agar keterampilan akademis dan fungsional mencerminkan pengetahuan dan keterampilan bermakna. Keterampilan yang disesuaikan dengan kebutuhan individual peserta didik dan berlaku untuk kehidupan sehari-hari sehingga kualitas tujuan hidup berkembang di luar rumah, seperti pertemanan, partisipasi masyarakat, dan pekerjaan.

Perspektif pandangan guru yang mengetengahkan asas fungsional pengembangan kurikulum pendidikan khusus merupakan kerangka pikir yang perlu diapresiasi di tengah berbagai stigma tentang profesi guru yang menipis. Pembahasan pandangan gagasan ini seperti memberi semangat tim pengembang kurikulum tentang hasil rancangannya yang kuat secara fungsional dalam konteks SLB. Ide baru dalam konteks pengembangan kurikulum pendidikan khusus dengan melibatkan para guru harus diperhitungkan sebagai media modalitas perkembangan, kemajuan, dan keakuratan menjalani dinamika kemasyarakatan mereka bersama peserta didik berkebutuhan khusus. Dengan azas fungsional dalam perancangan kurikulum, satu dari tiga pilar utama, selain keterampilan dan kompetensi yang mengonstruksi bangunan harapan atau optimisme pada tamatan SLB, nilai-nilai kehidupan adalah tujuan utamanya.

\section{Asas Kemandirian}

Asas pengembangan kurikulum pendidikan khusus yang tidak kalah penting adalah yang berorientasi pada melatih, mendampingi, dan membantu peserta didik berkebutuhan khusus memecahkan masalah agar dapat tumbuh kembang dengan wajar dan mampu mengoptimalkan potensi yang ada pada dirinya sehingga menjadi orang yang mandiri. Kemandirian dapat dimulai dari hal-hal yang sangat sederhana, seperti mampu memasang atribut diri (memakai dan mencopot baju, memasang sepatu, memasang kaos kaki, dan membawa tas sekolah), mengurus diri (mandi, makan, minum, menyiapkan perangkat sekolah, dan tidur), mengelola tugas, dan mengerjakan pekerjaan yang diberikan sampai pada mampu bekerja dengan orang lain. Dengan asas kemandirian dalam pengembangan kurikulum diharapkan tidak ada lagi stigma di masyarakat bahwa peserta didik berkebutuhan khusus dikategorikan sebagai masyarakat yang rapuh dan tidak mampu berbuat apa-apa.

Kemandirian peserta didik berkebutuhan khusus berkaitan erat dengan kinerja mereka dan sangat bergantung pada muatan-muatan kurikulum yang dikonseptualisasikan guru mereka. Kerangka berpikir seperti itu sejalan dengan hasil penelitian Dean dan Fornaciari (2013) yang melakukan pengamatan selama lima tahun terus-menerus berkait dengan struktur kursus dan rutinitas, seperti parameter tugas, peraturan proses kelompok peserta didik, dan skema penilaian secara konsisten dapat dijadikan rujukan. Dalam penelitian tersebut Dean dan 
Fornaciari menemukan bahwa kemandirian dan kinerja peserta didik dapat ditingkatkan dengan sangat baik dan sesuai hasil belajar yang diinginkan apabila dapat dipupuk dengan menawarkan jenis struktur tertentu kepada mereka, dengan cara-cara tertentu pula, seperti kegiatan pramuka, kursus, pemberian tugas, dan instruktur yang kapabel. Hasil studi ini memberi makna bahwa apa pun asas pengembangan kurikulum, apabila dalam praktik pembelajarannya kurang kuat menumbuhkembangkan mental mandiri, maka kemandirian tidak bisa tumbuh dengan kuat.

Menjadikan peserta didik berkebutuhan khusus menjadi mandiri juga sangat bergantung bagaimana pembelajaran dapat difokuskan pada penghalang-penghalang yang menghambat di lingkungan fisik, sosial, budaya, dan ekonomi sehingga mereka bisa berpartisipasi dan memberikan kontribusi sesuai dengan potensi dan kemampuan yang dimiliki. Misalnya, jangan karena mereka memiliki kekurangan dan hambatan kemudian terus dijadikan stigma tidak bisa berbuat apa-apa. Padahal, etos dan kemandirian sangat dibutuhkan, antara lain di bidang pendidikan, pekerjaan, perilaku sosial, pembangunan kapasitas, perspektif pilah gender, dan pemenuhan hak-hak mereka. Kemandirian bukan berarti berkesendirian, melainkan adanya berani berpikir, bersikap, berdaulat, dan bertindak secara sendiri dalam mengarungi hidup. Menurut gagasan para guru, telah ada upaya untuk mentransformasi pemikiran yang menjembatani segala sesuatu yang telah ada saat ini (what it is) dan segala sesuatu yang seharusnya ada di masa yang akan datang (what should be next) dalam kurikulum pendidikan khusus.

Pada sisi lain, pengembangan kurikulum pendidikan khusus hendaknya juga mempertimbangkan berbagai sebab lain sehingga peserta didik menjadi lebih siap dalam memasuki kehidupan di masyarakat. Salah satu indikator kesiapan memasuki kehidupan di masyarakat adalah kemampuan pengendalian diri. Tinggi rendahnya kemampuan peserta didik berkebutuhan khusus dalam mengendalikan diri akan mempengaruhi persepsi orangtua pada proses pendidikan. Meinert dan Reinecke (2017) melakukan studi untuk menguji stabilitas dan perubahan pengendalian diri selama masa remaja dan menyelidiki hubungan timbal balik kontrol diri dan kontrol sosial orangtua. Dalam studi tersebut diungkapkan bahwa pengendalian diri yang rendah mempengaruhi persepsi kontrol orangtua pada awal masa remaja. Karena itu, kurikulum pendidikan khusus yang dikembangkan dengan asas memandirikan menjadi sangat relevan.

Relevansi pandangan guru dengan mengetengahkan asas kemandirian pada pengembangan kurikulum pendidikan khusus juga bermakna mengarahkan karakteristik yang diorientasikan pada upaya memecahkan masalah-masalah yang dihadapi peserta didik berkebutuhan khusus menjadi manusia yang mandiri. Misalnya, mereka dilatih mampu mengurus segala keperluan diri sendiri setiap hari, mampu menyelesaikan tugas dan pekerjaan sendiri, pergi ke sekolah, menjadi lebih percaya diri, dan bekerja sehingga memperoleh penghasilan. Selain itu, kurikulum tersebut juga diperlukan untuk memandirikan peserta didik berkebutuhan khusus mengatasi masalah keterbatasan akses, atau ketidakbisaan memasuki sekolah formal/reguler karena adanya berbagai keterbatasan, hambatan, dan kekurangan yang mereka miliki.

Konteks pandangan guru sebagaimana diungkap di atas dapat diartikan, bahwa asas kurikulum yang diyakini akan mampu mewadahi aktivitas pada etos dan logos peserta didik berkebutuhan khusus sehingga mereka dapat diarahkan untuk bisa berperilaku tidak bergantung pada orang lain. Asas tersebut sekaligus juga sebagai upaya mengarahkan penciptaan ruang kreatif, arena sosial atau publik yang produktif sehingga mereka juga semakin mandiri. 
Hasil pengembangan kurikulum yang digagas dengan asas kemandirian peserta didik berkebutuhan khusus merupakan sebuah jawaban yang didambakan banyak pihak. Pada konteks ini, hasil perancangan kurikulum yang sarat dengan muatan kecakapan kewirausahaan bisa menjadi arah dan tujuan. Nilai-nilai kewirausahaan dapat diinternalisasikan kepada peserta didik berkebutuhan khusus dengan ragam strategi, misalnya memproduksi dan menjual hasil-hasil karya keterampilan mereka kepada masyarakat secara langsung. Kecakapan kewirausahaan tidak bisa begitu saja dimunculkan, harus ada proses pemupukan yang panjang dan perlu waktu lama ke dalam diri mereka. Di sinilah urgensi perluasan asas kemandirian yang sarat dengan keterampilan, kompetensi, dan kualitas karakter ke kapabilitas personal sesuai dengan tuntutan kecakapan abad-21. Sebagai salah satu asas kurikulum, misalnya, implementasi kecakapan berwirausaha bisa dibangun pada saat ada unit produksi di sekolah. Unit produksi tersebut bisa mewadahi kreasi dan menjual hasil produk peserta didik berkebutuhan khusus sehingga keuntungan yang didapat dirasakan oleh mereka. Pengalaman berwirausaha seperti ini yang harus dipupuk dan dipraktikkan selama mereka mengikuti pendidikan.

Dengan asas mandiri dalam pengembangan kurikulum peserta didik berkebutuhan khusus akan menjadi lebih mandiri dan lebih baik dan tujuan untuk sama seperti yang dialami kebanyakan orang normal akan tercapai. Semangat sebuah rancangan kurikulum yang mengarah pada tumbuh dan berkembang peserta didik tujuan utamanya. Dengan demikian, harga diri dan jati diri mereka terus terbangun dan memperoleh spirit dari orangorang di sekitarnya. Kurikulum yang mampu memandirikan ini merupakan pokok agar mereka bisa memiliki semangat, cita-cita, kebahagiaan, bukan menerima keadaan sebagai belenggu kehidupan.

\section{Asas Literasi}

Salah satu kristalisasi temuan dari FGD dengan para guru adalah apapun hasil kurikulum yang dikembangkan asas literasi juga dijadikan prinsip dasar pijakan. Asas literasi sangat penting karena salah satu ukuran keberhasilan pembangunan pendidikan khusus berkualitas adalah kecakapan literasi lulusan. Pandangan praksis literasi tersebut harus dimaknai melampaui pengertian konvensionalnya, bukan sekadar kemampuan membaca dan menulis. Kecakapan tersebut sebagai upaya peningkatan kesadaran dan pengakuan atas kemampuan literasi, seperti baca tulis berhitung, informasi, sains, ekonomi, teknologi, keuangan, dan lain sebagainya. Pandangan gagasan guru seperti itu, menandakan bahwa konten pengembangan kurikulum seyogianya juga diorientasikan pada pemecahan masalah pemahaman dan pemaknaan kebahasaan dalam konteks kehidupan. Pemaknaan kebahasaan dapat mengasah dan meningkatkan aneka keterampilan dan kecakapan sehingga membuat peserta didik berkebutuhan khusus dapat berkarya lebih efisien.

Kecakapan literasi harus menjadi masukan semua pemangku kepentingan pendidikan khusus untuk mendorong berkembangnya literasi peserta didik berkebutuhan khusus berperilaku karena adanya proses pendidikan untuk memahami, mencerna, dan menganalisis. Kecakapan literasi bukan sekadar memahami narasi, melainkan juga mengacu pada konsep, alat, dan pengalaman melek informasi (MachinMastromatteo, 2014). Berdasarkan hasil penelitian Bønløkke, Kobow, dan Kristensen (2012) terkait literasi informasi dalam profesi keperawatan menyimpulkan bahwa literasi informasi adalah kompetensi yang dibutuhkan. Kompetensi tersebut masuk akal bagi peserta didik bila dikaitkan dengan tugas, tepat waktu, dipersiapkan, sistematis, dan berkesinambungan. Dua konsep dasar hasil penelitian tersebut memberi makna bahwa apa pun latar 
belakang pribadi peserta didik, kecakapan melalui praksis literasi adalah penting. Hal tersebut penting karena bukan sekadar pemahaman melainkan juga panduan bersikap dan berperilaku guna membentuk karakter yang dinamakan literate.

Cakupan literate yaitu menyangkut proses membaca, mencari bacaan, menganalisis, mengevaluasi, dan kecakapan menggunakan informasi. Asas literasi dalam pengembangan kurikulum berkait dengan masalah kecakapan hidup, sekaligus merupakan kebutuhan hidup peserta didik berkebutuhan khusus. Literasi bukanlah sesuatu yang stagnan menurut Dewayani dan Retnaningyah (2017). Literasi berubah berkaitan dengan pengetahuan dan cara berpikir. Dengan demikian, asas literasi pengembangan kurikulum dapat dijadikan arena dan memberikan bekal kepada peserta didik berkebutuhan khusus untuk menghadapi ketidakberdayaan agar mereka menjadi literate. Untuk memiliki kecakapan yang literate, menurut Spooner, Kemp-Inman, Ahlgrim-Delzell, Wood, dan Davis (2015), adalah melalui penggunaan cerita bersama. Perspektif pandangan guru ini memberikan catatan bahwa berdasarkan pengalaman ternyata guru memiliki kepekaan untuk memastikan dan mengoreksi kecakapan melalui kecakapan literasi yang harus dimuat dalam kurikulum sekolah mereka.

Scheibe (2004) merekomendasikan keaksaraan media dapat digunakan secara efektif sebagai pendekatan pedagogis untuk mengajarkan konten inti di kurikulum K-12. Kebutuhan guru dan peserta didik dengan mempromosikan keterampilan berpikir kritis, komunikasi, dan teknologi dapat dipenuhi. Hasil kajian ini memberi makna, bahwa keterampilanketerampilan literate yang dimaksud perlu menjadi pertimbangan asas pengembangan kurikulum pendidikan untuk seluruh bangsa di dunia, termasuk peserta didik berkebutuhan khusus. Kerangka kerja pandangan guru akan menginspirasi berbagai pihak yang ber- kepentingan. Kurikulum pendidikan khusus menjadi lokomotif berbagai kecakapan melalui praksis literasi dasar sebagai pintu masuk tumbuh kembangnya peserta didik berkebutuhan khusus di sekolah, keluarga, dan masyarakat secara berkesinambungan. Prinsip dasar tersebut menjadi penuh makna karena literasi juga merupakan salah satu kecakapan untuk menumbuhkembangkan kemampuan bernalar dan meningkatkan kualitas hidup. Semangat berliterasi ini senada dengan perkembangan literasi dunia yang dihasilkan dalam Forum Ekonomi Dunia pada tahun 2015 di Paris.

Kecakapan literasi juga merupakan kemampuan hidup (life skill) yang menjadi kebutuhan hidup masyarakat. Dengan demikian, asas pengembangan kurikulum bersandarkan pada prinsip kecakapan literasi diperlukan sebagai upaya untuk meningkatkan kualitas diri peserta didik berkebutuhan khusus. Ketika taraf hidup akan ditingkatkan, maka diperlukan keterampilan baru yang lebih, yaitu mengetahui, memahami, dan memaknai kebahasaan dan sistem perbendaraan kata dalam konteks kehidupan dan estetika dengan cara pandang penggunaan bahasa. Cara pandang apa pun dalam mengajarkan literasi pada area konten kurikulum, menurut Collin (2014) adalah bagaimana mengumpulkan wacana dari berbagai bidang cara membaca, menulis, berbicara, berpikir, dan mendengarkan yang berbeda.

Strategi memperoleh kecakapan melalui praksis literasi hanya bisa dimiliki peserta didik berkebutuhan khusus dengan menjalani proses belajar melalui kurikulum. Dalam proses belajar, memerlukan pemahaman yang benar dan tepat. Agar benar dan tepat, maka penerapan program asesmen kebutuhan dan potensi sumber daya perlu dirumuskan dengan baik. Hal ini diperlukan sebagai pijakan dasar sehingga praktik pembelajaran dapat dijalankan sesuai kebutuhan dan tepat sasaran. Bagi peserta didik berkebutuhan khusus, moda pembelajaran literasi dasar ini akan menentukan pula perilaku 
literate terhadap banyaknya informasi yang dapat diserap secara kritis, logis, dan tidak mudah diperdaya oleh informasi menyesatkan yang diterimanya.

Begitu mudah dan banyaknya informasi, maka kemampuan mencari, mengevaluasi, menganalisis, dan menggunakan informasi seyogianya terpancar dalam pengembangan kurikulum yang dibutuhkan untuk dapat digunakan sebagai bahan memecahkan masalah kehidupan secara efektif. Pada satu sisi, dengan menguasai kecakapan literasi secara baik peserta didik berkebutuhan khusus dapat menciptakan bukan hanya keberaksaraan berbasis keterampilan (skills-based literacy) melainkan juga memanfaatkan secara etis. Di sisi yang lain, dengan kecakapan literasi yang kuat peserta didik SLB bisa menunjukkan kepada kalangan pemakai lulusan agar tidak ragu terhadap keberadaan sekolah mereka. Kalangan pemakai bisa terus memberi masukan atas beberapa persoalan yang dihadapi lulusan SLB saat ini, tidak sebatas kecakapan literasi, tetapi lebih dari itu.

\section{Asas Vokasi}

Pada saat FGD para guru juga memberikan pandangan bahwa asas vokasi harus dijadikan prinsip dasar dalam mengembangkan kurikulum pendidikan khusus. Asas vokasi (selanjutnya ditulis dengan istilah kejuruan) yang tepat sangat dibutuhkan peserta didik berkebutuhan khusus. Guru meyakini bahwa kurikulum kejuruan sarat dengan muatan untuk mengasah keterampilan dan kemampuan kejuruan pada saat bekerja. Pandangan para guru tersebut dapat dimaknai sebagai memiliki harapan besar agar lulusan SLB terlatih etos kerja, kecakapan kerja, dan budayanya sehingga mereka siap bekerja. Hal ini berarti, kapasitas peserta didik berkebutuhan khusus yang telah lulus ditentukan bukan hanya kemampuan diri mereka semata, melainkan sebagai hasil olah dan asah keterampilan dan kompetensi kejuruan dalam koridor kurikulum. Muatan keterampilan dan kompetensi kejuruan tersebut diarahkan mengubah keadaan atau lingkungan sekitar untuk mengembangkan kapasitas diri mereka dengan bermodalkan keterampilan membuat produk dan atau layanan jasa.

Guru berpandangan bahwa sebuah kurikulum pendidikan khusus dikembangkan atas dasar asas kejuruan. Dengan demikian, hambatan yang bersifat struktural dan fungsional berkaitan dengan keterampilan dan kemampuan yang dibutuhkan peserta didik berkebutuhan khusus bisa diatasi. Menguasai keterampilan dan kompetensi kejuruan amat penting, mengingat selama ini kemampuan lulusan peserta didik berkebutuhan khusus untuk mendapatkan pekerjaan masih menjadi masalah yang memerlukan pemecahan segera. Kenyataan bahwa lulusan kurang memiliki kesempatan untuk mendapatkan pekerjaan di sektor formal dibandingkan dengan pekerjaan di sektor nonformal maupun informal juga belum berubah. Sudiarja (2014) menyatakan bahwa pendidikan saat ini bagaikan model bank, yang hanya menumpuk pengetahuan dalam kepala peserta didik, belum mengubah situasi. Situasi dimaksud bisa mengarah pada keterampilan dan kemampuan bekerja yang selaras dengan perkembangan kebutuhan seseorang.

Bekal keterampilan dan kompetensi bidang kejuruan bagi peserta didik berkebutuhan khusus bukan hanya penting untuk bekerja, melainkan juga mampu mengembangkan keterampilan, kemampuan, kecakapan kerja, pemahaman, sikap, budaya kerja, dan apresiasi. Adhikary (2005) menyebutkan bahwa peserta didik yang menguasai bidang kejuruan mampu memasuki pekerjaan dan membuat kemajuankemajuan dalam pekerjaan secara penuh makna dan produktif. Hasil penelaahan Ritter, Small, Mortimer, dan Doll (2017) terhadap kebutuhan para pengusaha di lingkungan kerja menyimpulkan bahwa desain perancangan ulang kurikulum saat ini agar fokus pada penyusunan 
soft-skills bagi pekerja. Simpulan hasil telaah Ritter, et al. tersebut memberi makna bahwa kurikulum yang dikembangkan perlu mempedulikan aspek-aspek potensi peserta didik yang terkait dengan domain afektif untuk penguatan soft-skills yang seimbang dengan hard-skills. Asas kejuruan dalam mengembangkan kurikulum di samping berguna sebagai bekal peserta didik berkebutuhan khusus, bermanfaat pula bagi masyarakat dan bangsanya serta bagi umat manusia secara keseluruhan.

Bagi peserta didik berkebutuhan khusus mampu menguasai bidang kejuruan yang dilatihkan melalui kecakapan soft-skills yang seimbang dengan hard-skills merupakan koridor penting. Hal ini amat diperlukan agar memiliki daya terampil dan kompetensi yang dituntut pasar kerja serta dunia usaha dan dunia industri (DUDI). Asas vokasi pada pengembangan kurikulum akan menjadikan peserta didik berkebutuhan khusus lebih berdaya dalam menjawab tantangan pekerjaan. Demikian pula, saat mereka memasuki arena masyarakat menjadi lebih siap, tangguh, dan produktif. Berbekal keterampilan dan kemampuan bidang kejuruan dapat mendorong harga diri, martabat dan eksistensi, dan identitas diri mereka dengan segala aktivitas dan kekurangan yang dimilikinya menjadi kuat. Mereka akan berdaya karena rancangan kurikulum dan praktik kejuruan yang lebih baik sehingga mereka mampu mengatasi masalah sosial-ekonominya

Arah rancangan kurikulum pendidikan khusus yang bermuatan kecakapan bidang kejuruan tersebut selaras dengan laporan World Bank (2010) yang menyebutkan agar lulusan kejuruan bisa diterima oleh pemberi kerja, yang dibutuhkan saat ini bukan memperbanyak sekolah kejuruan melainkan mengembangkan keterampilan dan kemampuan untuk meningkatkan kualitas. Dasar mengembangkan keterampilan dan kemampuan melalui kurikulum kejuruan ialah cita-cita kemanusiaan universal, yakni bisa mandiri. Artinya, asas kejuruan sebagai kerangka kerja pengembangan kurikulum bertujuan menyiapkan pribadi dalam keseimbangan dan kesatuan organisasi, harmonis, dan dinamis guna mencapai tujuan hidup kemanusiaan.

Pada saat $F G D$ terungkap pula pandangan sebagian besar guru bahwa kecakapankecakapan lainnya sebagai pelengkap bidang kejuruan hendaknya juga menjadi pertimbangan. Menurut mereka, saat ini kecakapan nonvokasi juga sangat diperlukan mengingat adanya perubahan karakteristik dunia kerja. Jenis pekerjaan yang memerlukan keterampilan yang lebih umum justru makin dibutuhkan. Menurut Fadel (2008) maupun Fadel, Bialik, dan Trilling (2009) kecakapan-kecakapan nonvokasi yang merupakan kecakapan hidup dan berkarier yang kini sangat dibutuhkan, di antaranya: 1) berpikir kritis dan mengatasi masalah; 2) kecakapan berkomunikasi; 3) kecakapan berkolaborasi; dan 4) kreativitas dan inovasi. Keempat kecakapan tersebut dikenal dengan the $21^{\text {st }}$ century skills. Bahkan, merujuk pada kajian yang dilakukan Fadel, Bialik, dan Trilling (2015), kecakapan kolaborasi yang melibatkan orang-orang dengan beragam latar belakang, kecakapan, dan perspektif akan semakin dibutuhkan karena masalah dan tantangan yang dihadapi dunia semakin kompleks.

Konten kurikulum pendidikan khusus memerlukan muatan the $21^{\text {st }}$ century skills karena pekerjaan sektor jasa akan tumbuh dengan pesat, dan permintaan pasar kerja akan pekerja terampil semakin tinggi (Jerald, 2009). Pekerjaan dengan upah tinggi akan semakin membutuhkan lebih banyak kompetensi pendidikan yang bercirikan soft-skills. Dengan dibekali kecakapan soft-skills dan hard-skills yang seimbang akan menghasilkan peserta didik berkebutuhan khusus yang sigap, ulet, cekatan, dan tangguh. Ketangguhan maupun ketidaktangguhan lulusan sangat bergantung pada rencana tertulis program pembelajaran dan 
unsur yang melaksanakan program tersebut. Apabila di SLB terdapat satu unsur yang tidak selaras maka hasil belajar untuk mencapai ketangguhan tadi sulit diwujudkan. Implementasi kurikulum dengan paradigma asas kejuruan memerlukan sinergi antarunsur-unsur warga sekolah, unsur masyarakat nondisabilitas dan unsur masyarakat disabilitas, serta unsur pemakai lulusan.

Dari pandangan guru di atas yang dimaknai sebagai kerangka berpikir, dapat ditarik benang merah bahwa asas pengembangan kurikulum pendidikan khusus yang fokus menempatkan objek bidang kejuruan sebagai bahan kajian utama merupakan keharusan. Oleh karena itu, semua mata pelajaran yang distrukturkan dalam kurikulum pendidikan khusus hendaknya mendukung pencapaian keterampilan dan kompetensi kejuruan yang dikehendaki. Dengan demikian, isi dan tujuan pembelajaran yang semangatnya merupakan muatan-muatan kejuruan harus dipilih dan dipilah agar dapat mengembangkan seoptimal mungkin keterampilan dan kemampuan peserta didik berkebutuhan khusus.

Demikian pula seluruh tujuan pendidikan bidang kejuruan hendaknya diorientasikan pada aktivitas dan kekhususan bidang tersebut, baik dalam hal isi maupun pelaksanaannya. Dampak dari asas kejuruan dalam pengembangan kurikulum akan memiliki daya tawar yang relatif tinggi bagi peserta didik berkebutuhan khusus untuk bekerja dan mencari pekerjaan. Karena terampil, kompeten, dan kapabel, mereka akan mampu menyelaraskan dengan profesinya. Menyiapkan mereka memiliki sebuah profesi dan bekal kejuruan merupakan kapasitas penting yang harus dimiliki para pengembang kurikulum.

Bekal kurikulum yang sarat dengan asas kejuruan yang tepat guna akan menjadikan lulusan lebih siap menghadapi kebutuhan DUDI. Selain peserta didik berkebutuhan khusus memiliki keterampilan dan kompetensi layanan jasa dan produksi pada bidang kejuruan tertentu, mereka juga dapat mendorong munculnya tenaga kerja kompetitor. Selain menjadi tenaga kerja yang terampil, mereka juga diharapkan memiliki kecakapan hidup untuk membuka usaha baru atau menciptakan profesi baru sehingga berdampak terhadap perekonomian negara secara keseluruhan. Melengkapi peserta didik berkebutuhan khusus dengan kemampuan hidup yang kaya dengan pelatihan kejuruan akan dapat menjadi penentu pertumbuhan suatu negara (Sulaiman, Bala, Tijani, Waziri, \& Maji (2015); Pilz, Krisanthan, Krisanthan, Zenner, \& Li (2016)). Peserta didik berkebutuhan khusus yang tumbuh dengan memiliki keterampilan, kemampuan, dan kecakapan sebagi modal dasar akan mampu berkontribusi pada diri sendiri, keluarga, masyarakat, dan negara. Bahkan, mampu menepis stigma anggapan sebagian masyarakat bahwa mereka tidak berdaya.

Agar rancangan kurikulum pendidikan khusus mampu memenuhi harapan sebagaimana sudut pandang guru di atas, salah satu tugas utama pengembang kurikulum adalah mengetengahkan asas pengembangan kurikulum yang sarat dengan muatan kompetensi kejuruan. Muatan kompetensi kejuruan tersebut oleh Rychen (2009) disebut sebagai kompetensi kunci. Kompetensi kunci adalah kompetensi untuk sebuah pekerjaan atau fungsi tertentu, tidak spesifik bagi pekerja tertentu atau industri tertentu, tetapi menopang kompetensi spesifik dari industri sehingga mempunyai nilai ekonomis.

Rancangan kurikulum yang berprinsip pada kejuruan dan penguasaan bidang kejuruan bagi peserta didik berkebutuhan khusus akan menjadi arah karena terkandung seperangkat muatan keterampilan dan kompetensi yang bermuara pada kemampuan bekerja dan berbudaya kerja. Kedua aspek tersebut dikembangkan dengan berorientasi pada penggabungan antara instruction dan construction dengan pendekatan utama pembelajaran yang mengacu pada frasa praktik kejuruan dan berorientasi pada hasil 
produk dan layanan jasa yang diinginkan. Kerangka berpikir tersebut sesuai dengan pendapat Toner (2010) yang mengatakan bahwa kurikulum yang mewadahi sistem pelatihan harus menjadi agen utama dalam proses pendidikan kejuruan.

Proses pengembangan kurikulum yang sarat dengan muatan kejuruan perlu melibatkan masyarakat sekitar sekolah, termasuk DUDI. Keterlibatan bisa dilakukan dengan cara dialog, urun gagasan, dan analisis kebutuhan. Hal ini untuk memastikan bahwa perancangan kurikulum SLB dapat menjawab tuntutan masyarakat/ komunitas sekitar. Konteks pelibatan ini dapat dimaknai sebagai ekosistem pendidikan antara sekolah, masyarakat, dan DUDI yang telah terjalin dengan baik. Jalinan ini sekaligus memberi garansi bahwa asas kejuruan dalam pengembangan kurikulum pendidikan khusus telah memiliki arah yang cermat.

Bergulirnya ekosistem pendidikan di lembaga pendidikan khusus dapat diartikan bahwa sumber daya sekitar sekolah memiliki pemahaman yang sama tentang pentingnya meningkatkan mutu sekolah. Hal ini menandakan bahwa kerangka kerja pandangan guru untuk menghasilkan kebijakan kurikulum sekaligus memiliki spirit penyusunan budaya dan ekonomi lokal. Dengan demikian, rasa memiliki masyarakat sekitar sekolah menjadi semakin kuat. Persepsi masyarakat menjadi terbangun karena lembaga pendidikan khusus yang ada mampu menyediakan layanan pendidikan bagi kebutuhan peserta didik berkebutuhan khusus. Lembaga tersebut sekaligus dapat mengatasi permasalahan sosial, pekerjaan, budaya, realitas, dan kebutuhan. Misalnya, daerah yang berada di tepi pantai bisa menyusun kurikulum pendidikan khusus tentang budi daya laut, seperti rumput laut, perikanan laut, kerajinan hasil laut, makanan hasil laut, dan lain sebagainya.

Di samping lima pandangan asas pengembangan kurikulum di atas, dari FGD guru juga menyampaikan sejumlah usulan lain terkait arah pengembangan kurikulum. Misalnya pengimplementasian kurikulum bagi peserta didik berkebutuhan khusus hendaknya mendorong perlakuan secara adil dan beradab. Tidak boleh ada diskriminasi perlakuan kepada mereka dalam beragam kegiatan di sekolah. Mereka juga diberikan pemberdayaan, fasilitas, dan perhatian yang sama agar mereka merasa bisa berprestasi dari kerja kerasnya sendiri dan maju karena pengalamannya sendiri.

Kebaikan-kebaikan yang dibangun akan lebih bermakna manakala dalam pengembangan kurikulum pendidikan khusus dilengkapi pula dengan muatan-muatan kompetensi masa depan. Semangat kompetensi masa depan disiapkan untuk tumbuhkembangnya potensi diri peserta didik berkebutuhan khusus memasuki era global yang oleh Pink (2006) disebut sebagai "conceptual era" atau era konseptual. Manusia yang akan berjaya dalam era tersebut, menurut Pink perlu memilki "Six high-concept and hightought senses in the conceptual age", yakni: 1)not just function but also design, 2) not just argument but also story,3) not just focus but also symphony,4) not just logic but also emphaty,5) not just seriousness but also play, and 6) not just accumulation but also meaning. Inti dari gagasan Pink (2006) ini menyiratkan bahwa prinsip dasar pengembangan kurikulum hendaknya juga memiliki arah dan tujuan masa depan yang jelas. Kejelasan tersebut akan memancar manakala dikendalikan dalam implementasinya, seperti proses pembelajaran yang menggairahkan, praksis keterampilan dan kemampuan yang bermakna, melewati praksis literasi, menebalkan empati terhadap sesama, dan menggerakkan semua indera peserta didik berkebutuhan khusus secara optimal.

Selain beragam asas yang dikemukakan di atas, masih dibutuhkan asas lainnya, seperti pemberdayaan, kecakapan abad-21, berbasis kewirausahaan, berbasis produksi, dan lainnya. Semakin lengkap dimensi asas kurikulum yang digagas berbagai pihak, semakin mampu 
kurikulum menangkap dan merepresentasikan kepentingan bersama warga bangsa dalam memperoleh pengetahuan praktis, kecakapan, keterampilan, literasi, dan kemampuan sesuai alam dan talenta peserta didik berkebutuhan khusus. Seikkula-Leino, Ruskovaara, Hannula, dan Saarivirta (2012) dalam studinya tentang Pendidikan Kewirausahaan di Finlandia mengatakan bahwa saat ini Uni Eropa (UE) menjadikan pembelajaran keterampilan kewirausahaan sebagai faktor penting dalam menciptakan kesejahteraan. Temuan studi ini memberi sinyal kuat bahwa nilai-nilai kewirausahaan amatlah penting diintegrasikan ke dalam muatan kurikulum pendidikan khusus. Faktor determinan adalah dihasilkannya peserta didik berkebutuhan khusus untuk meningkatkan kapasitas mereka dalam hal kecakapan kewirausahaan.

Pelibatan guru dari berbagai daerah merupakan sebuah strategi kerja yang cukup signifikan. Banyak ditemukan pemikiran dan pandangan yang sangat bagus dari para guru dalam pengembangan kurikulum pendidikan khusus. Beberapa pandangan guru dalam pengembangan kurikulum pendidikan khusus telah mampu memandu terwujudnya dokumen kurikulum yang memuat apa yang seharusnya ada dan cara yang baik yang harus mereka terapkan tanpa disertai catatan-catatan.

\section{SIMPULAN DAN SARAN \\ Simpulan}

Dari hasil penelitian disimpulkan bahwa dalam perancangan kurikulum pendidikan khusus untuk peserta didik berkebutuhan khusus para guru berpandangan bahwa kurikulum tersebut harus mengandung muatan-muatan pengetahuan praktis, kualitas karakter moral dan kinerja, keterampilan penting, kompetensi, seni, dan praksis literasi. Selain itu, keluwesan, fungsional, kemandirian, literasi, dan kejuruan merupakan asas-asas pengembangan kurikulum pendidikan khusus.

\section{Saran \\ Berdasarkan simpulan di atas, mekanisme perancangan kurikulum di masa yang akan datang perlu diperluas dengan melibatkan berbagai pihak yang berkepentingan dengan sumber daya yang representatif guna menghasilkan dokumen yang memiliki keseimbangan dan koherensi muatan sehingga tantangan yang menjadi isu utama bangsa segera dapat diatasi. Di samping itu, tim pengembang kurikulum pendidikan khusus pusat perlu menggali secara pedagogis dari sudut pandang lain guna melengkapi asas-asas kurikulum yang telah diungkap agar sebuah program pendidikan lebih bermakna menjawab tantangan, kebutuhan, kepentingan, dan harapan peserta didik berkebutuhan khusus.}

\section{PUSTAKA ACUAN}

Adhikary, P.K. (2005). Educational reform for linking skills development with employment in Nepal. In M. Singh (Eds.), Meeting basic learning needs in the informal sector integrating education and training for decent work. Empowerment and Citizenship (pp. 215-228). Hamburg, Germany: UNESCO Institute for Education.

Alwell, M. \& Cobb, B. (2009). Functional life skills curricular interventions for youth with disabilities a systematic review. Career Development for Exceptional Individuals, 32(2), 82-93.

Badan Perencana Pembangunan Nasional. (2015). Peraturan Presiden Republik Indonesia Nomor 2 Tahun 2015 tentang Rencana Pembangunan Jangka Menengah Nasional 2015-2019. Jakarta: Kementerian Perencanaan Pembangunan Nasional.

Berbiglia,V. A. (2011). The self-care deficit nursing theory as a curriculum conceptual 
framework in Baccalaureate education. Nursing Science Quarterly, 24(2), 137-145.

Bouck, E. C. \& Kulkarni, G. (2009). Middle-school mathematics curricula and students with learning disabilities: is one curriculum better? Learning Disability Quarterly, 32(4), 228244.

Bønløkke, M., Kobow, E. \& Kristensen, AK. (2012). Curriculum integrated information literacy a challenge. Nordic Journal of Nursing Research, 32(3), 53-55.

Chin, J., May, M.,Sullivan-Chin, H. \& Woodrick, K. (2014). How can social psychology and group dynamics assist in curriculum development? Teaching Sociology, 42(2), 86-94.

Cochran-Smith, M. \& Dudley-Marling, C. (2012). Diversity in teacher education and special education: the issues that divide. Journal of Teacher Education, 63(4), 237-244.

Collin, R. (2014). A Bernsteinian analysis of content area literacy. Journal of Literacy Research, 46(3), 306-329.

Collins, C. \& Yates, L. (2009). curriculum policy in south australia since the 1970s: the quest for commonality. Australian Journal of Education, 53(2), 125-140.

Dean, K. L. \& Fornaciari, C. J. (2013). Creating masterpieces: how course structures and routines enable student performance. Journal of Management Education, 38(1), 10-42.

Dewayani, S. \& Retnaningyah, P. (2017). Suara dari marjin: literasi sebagai praktik sosial. Bandung: Rosda.

Doabler, C. T., Clarke, B., Fien, H., Baker, S. K., Kosty, D. B., \& Cary, M. S. (2014). the science behind curriculum development and evaluation: taking a design science approach in the production of a tier 2 mathematics curriculum. Learning Disability Quarterly, 38(2), 97111.

Fadel, C. (2008). "Are they really ready to work?" report by the conference board, P21 et al. OECD/CERI. Paris: Education Cisco Systems, Inc.

Fadel, C., Bialik, M. \& Trilling, B. (2015). Four-dimensional education: the competencies learners need to succeed. Boston, MA: Center for Curriculum Redesign.

Figueiredo, C., Leite, C. \& Fernandes, P. (2016). The curriculum in school external evaluation frameworks in Portugal and England. Research in Comparative and International Education, 11(3), 282-297.

Gerrard, J., Albright, J., Clarke, D. J., Clarke, D. M.,Farrell, L., Freebody, P., et al. (2013). Researching the creation of a national curriculum from systems to classrooms. Australian Journal of Education, 57(1), 60-73.

Hamalik, O. (2007). Pengembangan Kurikulum. Bandung: Remaja Rosda Karya.

Hamilton, D., McFarland, D. \& Mirchandani, D. (2000). A decision model for integration across the business curriculum in the 21st century. Journalof Management Education, 24(1), 102-126.

Hollins, E. R. (2011). Teacher preparation for quality teaching. Journal of Teacher Education, 62, 395-407, doi:10.1177/0022487111409415.

Hunt, P., McDonnell, J. \& Crockett, M. A. (2012). Reconciling an ecological curricular framework focusing on quality of life outcomes with the and instruction of standards-based academic goals. Research and Practice for Persons with Severe Disabilities, 37(3), 139- 
152.

Jerald, C. D. (2009). Defining A $21^{\text {st }}$ century education. Alexandria, VA: The Center for Public Education.

Lamb, J. \& Branson, C. M. (2015). Educational change leadership through a new zonal theory lens: Using mathematics curriculum change as the example. Policy Futures in Education, 13(8), 1010-1026.

Lambert, D. (2013). Geography in school and a curriculum of survival. School Field, 11(1), 8598.

Leask, B. (2013). Internationalizing the curriculum in the disciplines-imagining new possibilities. Journal of Studies in International Education, 17(2), 103-118.

Li, Peidong \& Laidlaw, M. (2006). Collaborative enquiry, action research, and curriculum development in rural China: How can we facilitate a process of educational change? Action Research, 4(3), 333-350.

Machin-Mastromatteo, J. D. (2014). Thinking outside of literacy: Moving beyond traditional information literacy activities. Information Development, 30(3), 288-290.

Meinert, J. \& Reinecke, J. (2017). Self-control during adolescence: Examining the stability of low self-control and the effects of parental social controls. European Journal of Criminology.

Miller, D. L. (2011). Curriculum theory and practice: what's your style? Phi Delta Kappan, 92(7), 32-39.

Mogilner, C., Chance, Z. \& Norton, M. I. (2012). Giving time gives you time. Psychological Science, 23(10), 1233-1238.

Moore, A. (2015). Understanding the school curriculum: Theory, politics and principles. New York: Routledge.

Nasution, S. (2014). Asas-asas kurikulum. Jakarta: Bumi Aksara.

Nuttall, A. (2016). The 'curriculum challenge': Moving towards the 'Storyline' approach in a case study urban primary school. Improving Schools, 19(2), 154-166.

Pilz, M., Krisanthan, B., Michalik, B., Zenner, L. \& Li, Jun. (2016). Learning for life and/or work: The status quo of pre-vocational education in India, China, Germany and the USA. Research in Comparative and International Education, 11(2), 117-134.

Pink, Daniel H. (2006). A whole new mind: Why right-brainers will rule the future. New York: Riverhead Books.

Plotner, A. J. \& Dymond, S. K. (2016). How vocational rehabilitation transition specialists influence curricula for students with severe disabilities. Rehabilitation Counseling Bulletin 1-10, Hammill Institute on Disabilities 2016.

Pugach, M. C. \& Blanton, L. P. (2012). Enacting diversity in dual certification programs. Journal of Teacher Education, 63(4), 254-267.

Pusat Kurikulum dan Perbukuan. (2011). Naskah akademik penyusunan kurikulum, tidak Diterbitkan. Jakarta: Puskurbuk.

Richardson, J.T.E. (2005). Instruments for obtaining student feedback: a review of the literature. Assessment \& Evaluation in Higher Education 30(4), 387-415. 
Ritter, B.A., Small, E.E., Mortimer, J.W. \& Doll, J.L. (2017). Designing management curriculum for workplace readiness: Developing students' soft skills. Journal of Management Education, 42(1), 80-103.

Rock, M.L., Spooner, F., Nagro, S., Vasquez, E., Dunn, C., Leko, et al. (2016). 21st Century change drivers: considerations for constructing transformative models of special education teacher development. Teacher Education and Special Education, 39(2), 98-120.

Rychen, D.S. (2009). Key competencies: Overall goals for competence development: An international and interdisciplinary perspective. InR. Maclean, D. Wilson, dan C. Chinien (Eds. ). International Handbook of Education for the Changing World of Work, Bridging Academic and Vocational Learning (pp. 2571-2584). Germany: Springer.

Scheibe, C. L. (2004). A deeper sense of literacy: curriculum-driven approaches to media literacy in the K-12 classroom. American Behavioral Scientist, 48(1), 60-68.

Schleicher, A. (Ed.). (2012). Preparing Teachers and Developing School Leaders for the $21^{\text {st }}$ Century: Lessons from Around the World. Paris: OECD Publishing.

Schoenfeld, A.H. (2016). 100 Years of curriculum history, theory, and research. Educational Researcher, 45(2), 105-111.

Seikkula-Leino, J., Ruskovaara, E., Hannula, H. dan Saarivirta, T. (2012). Facing the changing demands of europe: Integrating entrepreneurship education in finnish teacher training curricula. European Educational Research Journal, 11(3), 382-399.

Siuty, M. B., Leko, M.M. \& Knackstedt, K.M. (2016). Unraveling the role of curriculum in teacher decision making. Teacher Education and Special Education, 41(1), 39-57.

Spence, K.K \& McDonald, M.A. (2015). Assessing vertical development in experiential learning curriculum. Journal of Experiential Education, 38(3), 296-312.

Spooner, F., Kemp-Inman, A., Ahlgrim-Delzell, L., Wood, L. \& Davis, L.L. (2015). Generalization of literacy skills through portable technology for students with severe disabilities. Research and practice for persons with severe disabilities, 40(1), 52-70.

Sudiarja, A. (2014). Pendidikan dalam tantangan zaman. Yogyakarta: PT Kanisius.

Sulaiman, C., Bala, U., Tijani, B.A., Waziri, S.I. \& Maji, I.K. (2015). Human capital, technology, and economic growth evidence from Nigeria. SAGE Open, 5(4).

Toner, P. (2010). Innovation and vocational education. The Economic and Labour Relations Review, 21(2), 75-98.

Trilling, B. \& Fadel, C. (2009). 21st century skills: Learning for life in our times. San Fransisco, CA: Jossey-Bass Publishing Co.

United Nations Children's Fund (UNICEF). (2013). Keadaan anak di dunia 2013 anak penyandang disabilitas. Rangkuman Eksekutif. Diterjemahkan ke dalam Bahasa Indonesia oleh Agus Riyanto. New York: Unicef.

World Bank. (2010). Education, training and labor market outcomes for youth in Indonesia. Jakarta: The World Bank Office Jakarta.

Zaini, M. (2009). Pengembangan kurikulum: Konsep implementasi evaluasi dan inovasi. Cetakan 1. Yogyakarta: Teras. 